\title{
Front Matter: Volume 9642
}

, "Front Matter: Volume 9642," Proc. SPIE 9642, SAR Image Analysis, Modeling, and Techniques XV, 964201 (29 October 2015); doi:

10.1117/12.2225955

SPIE. Event: SPIE Remote Sensing, 2015, Toulouse, France 


\section{PROCEEDINGS OF SPIE}

\section{SAR Image Analysis, Modeling, and Techniques XV}

\section{Claudia Notarnicola Simonetta Paloscia Nazzareno Pierdicca Editors}

23-24 September 2015 Toulouse, France

Sponsored by

SPIE

Cooperating Organisations

European Association of Remote Sensing Companies (Belgium) European Optical Society CENSIS-Innovation Centre for Sensor \& Imaging Systems (United Kingdom) EARSeL-European Association of Remote Sensing Laboratories

Optitec (France)

Route des Lasers (France)

Published by

SPIE 
The papers in this volume were part of the technical conference cited on the cover and title page. Papers were selected and subject to review by the editors and conference program committee. Some conference presentations may not be available for publication. Additional papers and presentation recordings may be available online in the SPIE Digital Library at SPIEDigitallibrary.org.

The papers reflect the work and thoughts of the authors and are published herein as submitted. The publisher is not responsible for the validity of the information or for any outcomes resulting from reliance thereon.

Please use the following format to cite material from these proceedings:

Author(s), "Title of Paper," in SAR Image Analysis, Modeling, and Techniques XV, edited by Claudia Notarnicola, Simonetta Paloscia, Nazzareno Pierdicca, Proceedings of SPIE Vol. 9642 (SPIE, Bellingham, WA, 2015) Six-digit Article CID Number.

ISSN: 0277-786X

ISSN: 1996-756X (electronic)

ISBN: 9781628418521

Published by

SPIE

P.O. Box 10, Bellingham, Washington 98227-0010 USA

Telephone +1 3606763290 (Pacific Time) · Fax +1 3606471445

SPIE.org

Copyright (c) 2015, Society of Photo-Optical Instrumentation Engineers.

Copying of material in this book for internal or personal use, or for the internal or personal use of specific clients, beyond the fair use provisions granted by the U.S. Copyright Law is authorized by SPIE subject to payment of copying fees. The Transactional Reporting Service base fee for this volume is $\$ 18.00$ per article (or portion thereof), which should be paid directly to the Copyright Clearance Center (CCC), 222 Rosewood Drive, Danvers, MA 01923. Payment may also be made electronically through CCC Online at copyright.com. Other copying for republication, resale, advertising or promotion, or any form of systematic or multiple reproduction of any material in this book is prohibited except with permission in writing from the publisher. The CCC fee code is 0277-786X/15/\$18.00.

Printed in the United States of America.

Publication of record for individual papers is online in the SPIE Digital Library.

\section{SPIE. DIGITAL}

Paper Numbering: Proceedings of SPIE follow an e-First publication model. A unique citation identifier (CID) number is assigned to each article at the time of publication. Utilization of CIDs allows articles to be fully citable as soon as they are published online, and connects the same identifier to all online and print versions of the publication. SPIE uses a six-digit CID article numbering system structured as follows:

- The first four digits correspond to the SPIE volume number.

- The last two digits indicate publication order within the volume using a Base 36 numbering system employing both numerals and letters. These two-number sets start with 00, 01, 02, 03, 04, $05,06,07,08,09,0 A, O B \ldots$ OZ, followed by 10-1Z, 20-2Z, etc. The CID Number appears on each page of the manuscript. 


\title{
Contents
}

\author{
$\checkmark \quad$ Authors \\ vii Conference Committee
}

\section{SAR APPLICATION I}

964202 Multitemporal retrieval of soil moisture from SMAP radar data at L-band [9642-1]

964204 Large area robust identification of snow cover from multitemporal COSMO-SkyMed images [9642-3]

964205 Land-cover classification in SAR images using dictionary learning [9642-4]

\section{SAR APPLICATION II}

964206 Cosmo-SkyMed and RADARSAT2 image investigation for the monitoring of agricultural areas (Invited Paper) [9642-5]

964208 Multi-temporal intensity and coherence analysis of SAR images for land cover change detection on the Island of Crete [9642-7]

9642 OA Canonical Huynen decomposition of radar targets [9642-9]

JOINT SESSION WITH CONFERENCE 9643: SAR DATA PROCESSING II

9642 OB Implementation of a fast time-domain processor for FMCW Synthetic Aperture Radar data [9642-10]

9642 OC Detecting earthquake damage in urban area: application to COSMO-SkyMed imagery of L'Aquila earthquake [9642-11]

9642 OD On the geolocation accuracy of COSMO-SkyMed products [9642-12]

9642 OE Visual analytics for semantic queries of TerraSAR-X image content [9642-13]

\section{SAR INTERFEROMETRY}

9642 OG Sparsity-driven autofocus for multipass SAR tomography [9642-16]

$9642 \mathrm{OH}$ An integrated remote sensing approach for landslide susceptibly mapping at the volcanic islands of Vulcano and Lipari (Eolian Island, Italy) [9642-17]

964201 The PSIG procedure to Persistent Scatterer Interferometry (PSI) using X-band and C-band Sentinel-1 data [9642-18] 
$9642 \mathrm{OL} \quad$ Advanced DInSAR analysis for building damage assessment in large urban areas: an application to the city of Roma, Italy [9642-21]

9642 OM Interferometric SAR imaging by transmitting stepped frequency chaotic noise signals [9642-22]

POSTER SESSION

9642 OP A new MIMO SAR system based on Alamouti space-time coding scheme and OFDM-LFM waveform design [9642-23]

9642 OR Refocusing of ground moving targets for range migration algorithm in FMCW SAR [9642-26]

9642 OT A comparison of feature extraction methods for Sentinel-1 images: Gabor and Weber transforms [9642-28]

$96420 \mathrm{U}$ Estimation and characterization of physical and inorganic chemical indicators of water quality by using SAR images [9642-29]

9642 OW Robust optical and SAR multi-sensor image registration [9642-31]

9642 OX Modeling algorithm for SAR image based on fluctuations of echo signal of the Earth's surface [9642-32]

$96420 Z$ A methodology for outperforming filtering results in the interferometric process [9642-35]

964210 Monitoring of urban villages in Shenzhen, China from high-resolution GF-1 and TerraSAR-X data [9642-36] 


\section{Authors}

Numbers in the index correspond to the last two digits of the six-digit citation identifier (CID) article numbering system used in Proceedings of SPIE. The first four digits reflect the volume number. Base 36 numbering is employed for the last two digits and indicates the order of articles within the volume. Numbers start with 00, 01, 02, 03, 04, 05, 06, 07, 08, 09, OA, OB...0Z, followed by 10-12, 20-2Z, etc.

Aiazzi, B., 04

Aktaş, Gizem, 05

Anniballe, R., OC

Alonso, Kevin, OE

Bak, Çağdaş, 05

Baronti, S., 04

Bignami, C., OC

Blaschke, Thomas, 10

Bonano, Manuela, OL

Bovenga, Fabio, OD

Bruno, Maria Francesca, OD

Bruzzone, L., 06

Cheng, Pu, OR

Chiaradia, Maria Teresa, OD

Chini, M., OC

Crippa, Bruno, 01

Crosetto, Michele, 0 I

Cuevas-González, María, 01

Cuozzo, G., 06

D'Aranno, Peppe, J. V., OL

Datcu, Mihai, OE

Demir, B., 06

Devanthéry, Núria, 01

Dong, Xiao, OM

Elias, P., 08

Espinoza-Molina, Daniela, OE

Fascetti, Fabio, 02

Frioud, Max, OB

Garzelli, A., 04

Greifeneder, F., 06

Greig, D., OG

Gu, Xiang, OM

Kang, Xueyan, OM

Karathanassi, V., OZ

Khenchaf, Ali, OU

Kontoes, C., 08

Li, Dong, OA

Lombardi, Nunzia, OD

Lorusso, Rino, OD

Mannella, A., OC

Marsella, Maria, $\mathrm{OH}, \mathrm{OL}$

Martinelli, A., OC

Meier, Erich, OB

Milillo, Giovanni, OD

Ming, Yang, OW

Monserrat, Oriol, ol

Muirhead, F., OG

Mulgrew, B., OG

Nar, Fatih, 05

\author{
Nenashev, Vadim A., OX \\ Nicolini, I., 06 \\ Nikolaeva, E., 08 \\ Nitti, Davide O., OD \\ Notarnicola, C., 06 \\ Noto, F., OC \\ Nutricato, Raffaele, OD \\ Palchetti, E., 04 \\ Palenzuela Baena, José A., $\mathrm{OH}$ \\ Paloscia, S., 04, 06 \\ Pepe, Susi, $\mathrm{OH}$ \\ Pettinato, S., 04, 06 \\ Pierdicca, Nazzareno, 02, 0C \\ Popescu, Anca, OT \\ Pulvirenti, Luca, 02 \\ Santi, E., 04, 06 \\ Sansosti, Eugenio, $\mathrm{OH}$ \\ Saqellari-Likoka, A., $\mathrm{OZ}$ \\ Scalia, T., OC \\ Scifoni, Silvia, OH, OL \\ Scutti, Marianna, OL \\ Şen, Nigar, 05 \\ Shareef, Muntadher A., OU \\ Shepeta, Alexander P., OX \\ Shi, Xiaojin, OM, OP \\ Solaro, Giuseppe, $\mathrm{OH}$ \\ Sonnessa, Alberico, OL \\ Stan, Mihaela, OT \\ Stanko, Stephan, OB \\ Stoichescu, Dan Alexandru, OT \\ Stramondo, S., OC \\ Sykioti, $0 ., 08$ \\ Taubenböck, Hannes, 10 \\ Tizzani, Piero, $\mathrm{OH}$ \\ Toumi, Abdelmalek, OU \\ Wan, Jianwei, OR \\ Wang, Zhan, OR \\ Wei, Chunzhu, 10 \\ Wellig, Peter, OB \\ Woodhouse, I. H., OG \\ Wu, Yingdan, OW \\ Xin, Qin, OR \\ Zhai, Wenshuai, OM \\ Zhang, Yunhua, OA, OM, OP
}


Proc. of SPIE Vol. $9642964201-6$

Downloaded From: https://www.spiedigitallibrary.org/conference-proceedings-of-spie on 26 Apr 2023 Terms of Use: https://www.spiedigitallibrary.org/terms-of-use 


\section{Conference Committee}

Symposium Cha ir

Charles R. Bostater, Florida Institute of Technology, Ma rine Environmental Optic s Laboratory and Remote Sensing Center (United States)

Symposium Co-chair

Kaus Sc häfer, Karlsruhe Institut für Technologie, Institute of Meteorology and Climate Research (Gemany)

Conference Chairs

Claudia Notamicola, EURAC Research (Italy)

Simonetta Paloscia, Istituto di Fisica Applicata Nello Carrara (Italy)

Nazzareno Pierdic ca, Università degli Studi di Roma La Sapienza (Italy)

Conference Programme Committee

Richard Bamler, Deutsc hes Zentrum für Luft- und Ra umfahrt e.V.

(Germany)

Fabio Bovenga, CNR ISSIA (Italy)

Fabio Covello, Agenzia Spazia le Italiana (Italy)

Mihai P. Datcu, Deutsches Zentrum für Luft- und Raumfahrt e.V. (Germany)

Fabio Del Frate, Università degli Studi di Roma "Tor Vergata" (Italy)

Linda E. Marc hese, INO (Canada)

Antonio Moc cia, Università degli Studi di Napoli Federico II (Ita ly)

Francesco Nirchio, Agenzia Spazia le Italia na (Italy)

Luca Pasolli, EURAC Research (Italy)

Luca Pulvirenti, CIMA Research Foundation (Italy)

Emanuele Santi, Istituto di Fisic a Applic ata Nello Carra ra (Italy)

Stefan Sc hneiderbauer, EURAC Resea rch (Italy)

David Small, University of Zurich (Switzerland)

Session Chairs

1 SAR Application I

Simonetta Paloscia, Istituto di Fisica Applicata Nello Carrara (Italy)

2 SAR Application II

Emanuele Santi, Istituto di Fisica Applic ata Nello Carra ra (Italy) 
SAR Data Processing I: J oint Session with Conference 9642

Lorenzo Bruzzone, Università degli Studi di Trento (Ita ly)

SAR Data Processing II: J oint Session with Conference 9643

Claudia Notamic ola, EURAC (Italy)

3 SAR Interferometry

Fabio Bovenga, CNR ISSIA (Ita ly)

4 SAR Processing and Interferometry

Nazzareno Pierdicca, Sa pienza Università di Roma (Italy) 